SELÇUK ÜNIVERSITESİ HUKUK FAKÜLTESİ DERGISII

Selçuk Law Review

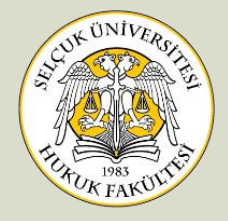

Araştırma Makalesi

Research Article

Gönderim / Received: 15.07.2021

Kabul |Accepted: 13.12.2021

doi) $10.15337 /$ suhfd. 972124

\title{
SHARENTING VE VELAYET HAKKININ SINIRLARI
}

Arş. Gör. Dr. Ayça ZORLUOĞLU YILMAZ*

Öz

İnternetin hızlı gelişimi sonucu sosyal medya platformlarının artışı tümüyle yeni istismar türlerinin de kapısını aralamıştır. Hem ana babaların hem de çocukların sosyal medya platformlarına erişimi kolaylaşmıştır. Sosyal medya platformlarında yapılan paylaşımların kontrolü zor olduğundan dolayı ihlaller de daha kolay gerçekleşmektedir. Bazı hallerde bu ihlaller üçüncü kişiler tarafından yapılmaktadır. Bazı hallerde ise ana babalar farkında dahi olmaksızın çocuklarına sosyal medya paylaşımları yoluyla zarar verebilmektedirler. Bu duruma sharenting adı verilmektedir. Problemin ana temeli, aslında bireylerin sosyal medyaya ilişkin gereği kadar bilgi sahibi olmamaları ve çocuklara ilişkin bu paylaşımların normalleştirilmesidir. Bu sayede aileler çocuklarının günlük aktivitelerini, rutinlerini, yaşadıkları yeri farkında dahi olmaksızın ifşa etmekte ve istemeden de olsa çocuklarını istismar tehlikesi ile karşı karşıya bırakmaktadırlar. Bu konu hakkında farkındalık yaratılmalı ve doğan hukuki sorunlara çözüm önerileri getirilmelidir.

\section{Anahtar Kelimeler}

Sharenting • Velayet • Çocuk • Dijital Kaçırma • Sosyal Medya

Arş. Gör. Dr., Hacettepe Üniversitesi Hukuk Fakültesi, Medeni Hukuk Anabilim

Dalı, Ankara, Türkiye I Res. Asst. PhD, Hacettepe University, Faculty of Law, Department of Civil Law, Ankara, Turkey.

$\varpi$ aycazorluoglu@gmail.com • ORCiD 0000-0001-7250-4097

At Atı Şekli @] Cite As: ZORLUOĞLU YILMAZ Ayça, “Sharenting ve Velayet Hakkının Sinirları", SÜHFD., C. 29, S. 4, 2021, s. 3383-3417.

I Intihal [ Plagiarism: Bu makale intihal programında taranmış ve en az iki hakem incelemesinden geçmiştir. ? This article has been scanned via a plagiarism software and reviewed by at least two referees. 


\title{
SHARENTING AND LIMITS OF CUSTODY
}

\begin{abstract}
The increase in social media platforms as a result of the rapid development of the Internet has opened the door to completely new types of abuse. Access to this technology has become easier for both parents and children. Since it is difficult to control the shares made on social media platforms, violations are also easier. In some cases, these violations are committed by third parties, while in some cases, parents may harm their children through social media posts without even realizing it. This situation is called sharenting. The main basis of the problem is that individuals do not have enough information about social media and the normalization of these shares about children. In this way, families unwittingly reveal their children's daily activities, routines and place of residence, and unintentionally expose their children to the danger of abuse. Awareness should be raised on this issue and solutions should be offered to the legal problems that arise.
\end{abstract}

\section{Key Words}

Sharenting $\bullet$ Custody $\bullet$ Child $\bullet$ Digital Kidnapping $\bullet$ Social Media

\section{GİRIŞ}

Teknolojinin gelişimi sonucu sosyal medya kullanımının hızla artışı ile ebeveynler en kıymetli varlıkları olarak gördükleri çocuklarına ilişkin pek çok paylaşım yapmaktadırlar. Fakat ana babalar, çocukları henüz doğmadan önce onlar adına açtıkları sosyal medya hesapları ve bu hesaplarda paylaşılan ultrason fotoğrafları yoluyla, farkında dahi olmaksızın çocuklarının bir dijital ayak izine sahip olmasına yol açmaktadırlar. İnternet ve buna bağlı olarak sosyal medyanın kullanımının yaygınlaşması ile bu araçların bilinçsiz kullanımı sorunları ortaya çıkmıştır. Kendini koruyamayacak durumda olan çocukların kişilik hakkı, çoğu zaman bunun farkında bile olmayan aileleri tarafından, sosyal medya araçları vasıtasıyla ihlal edilebilmektedir. Özellikle pandemi döneminde, ailelerin ve çocukların evde daha uzun birlikte zaman geçirmeleri, bu paylaşımların da sayısını arttırmıştır. Ebeveynler fotoğraf ve video paylaşımına uygun olan platformlar 
aracılığıyla kendilerinin ve çocuklarının günlük aktivitelerini, rutinlerini, özel günlerini, yaşadıkları yeri, adeta hayatlarının her noktasını detaylıca yayınlamaktadırlar. Hatta ebeveynler, kendi çocuklarını örnek olarak göstermek suretiyle yaptıkları sosyal medya paylaşımları vasıtasıyla gelir elde etmeye çalışmaktadırlar. Bu eylem, potansiyel olarak gelir elde etmenin yanı sira anne babalara, kendileri ile benzer durumda olan ailelere ulaşma ve iletişim kurma, hatta bazı durumlarda dayanışma imkânı gibi avantajlar da sağlamaktadır.

Anne babaların, çocukları üzerinde velayet hakkı bulunmaktadır. Fakat velayet bir hak olduğu kadar, aynı zamanda bir yükümlülüktür. Buna göre ana baba, çocuğun kişilik hakkının korunması ve geliştirilmesi, malvarlığı haklarının korunması için gereken her türlü özeni göstermekle yükümlüdür. Çocuk ile ilgili karar alırken, çocuğun üstün yararının gözetilmesi zorunludur. Bu hak ve yükümlülük hem Anayasa hem Türk Medeni Kanunu hem de Birleşmiş Milletler Çocuk Hakları Sözleşmesi ile korunma altına alınmıştır. Anne babalar, bilinçsizce yaptıkları sosyal medya paylaşımları ile çoğu zamanda farkında bile olmaksızın çocuklarının mahremiyetini, kişilik hakkını ve unutulma hakkını ihlal edebilmektedirler. Hatta bu paylaşımları ile çocuklarını adeta ucu bucağı bilinmez bir sanal ortam olan sosyal medyada ifşa etmekte ve çocuklarını istismar edilme tehlikesi ile karşı karşıya bırakabilmektedirler. Fotoğraf ve video paylaşımı imkânı sunan sosyal platformlar aracılığıyla çocuğun kişisel verisi niteliğinde olan görüntüsü ve sesi, başka kullanıcılar tarafından kopyalanmakta, kesilip yapıştırılmak suretiyle değiştirilmekte ve kontrolsüz olarak başka platformlarda paylaşılmaktadır.

Çalışmamızda, konu üç ana başlık altında ele alınmıştır. İlk olarak sharenting kavramı üzerinde durulmuş ve bu eylem sonucu doğabilecek potansiyel tehlikelere işaret edilmeye çalışılmıştır. İkinci başlıkta ana babanın velayet hakkı ve bunun sınırları değerlendirilmiş, bu kapsamda da çocuğun üstün yararı, çocuğun kişilik hakkı ve mahremiyetine değinilmiştir. Üçüncü başlıkta ise çocuğun haklarının sharenting eylemi sonucunda ihlal edilmesi sebebiyle başvurulabilecek hukuki yaptırımlar üzerinde durulduktan sonra bu hukuki korumaların yanı sıra son olarak 
çocuğun kişilik hakkını ve mahremiyetini sosyal medya aracılığıyla ihlal etmemek için alınabilecek önlemlere yer verilmiştir.

\section{I.SHARETING KAVRAMI ve DOĞABİLECEK HUKUKİ PROBLEMLER}

\section{A. SHARENTING KAVRAMI}

Sosyal medya araçları ile ehliyetsiz durumda olan bir çocuğun hakları ebeveynleri veya üçüncü kişiler tarafından fotoğraf ve video paylaşımı yoluyla ihlal edilebilmektedir. Ana babanın, çocuklarına ait fotoğraf ve videoları sosyal medya araçları aracılığıyla yayınlamasına, literatürde "share" ve "parent" sözcüklerinin birleştirilmesiyle oluşmuş yeni bir kavram olan "sharenting" adı verilmektedir. Aileler, her ne kadar bu paylaşımları kapalı hesapları yoluyla doğrudan kamuya açık olarak değil, fakat sınırlı bir çevreye duyurduklarını düşünseler dahi, ilerleyen teknoloji ile gelişen kopyalama ve saklama uygulamaları ile bu paylaşımlar depolanabilmekte ve ihlale konu olabilmektedir ${ }^{1}$.

Sosyal medya uygulamalarının artışı ile sharenting de günden güne katlanarak artmaktadır. Çocuk henüz doğmadan dahi, adına sosyal medya hesapları açılmakta, yapılan her paylaşım ile çocuğa ilişkin yeni dijital ayak izi meydana getirilmektedir. Bu yapılan paylaşımlarda çocuklarının yüzlerinin görünmesine de büyük oranda dikkat edilmemektedir².

Ebeveynlerin çocuklarına ilişkin ses ve görüntü paylaşımları zaman içerisinde çocuğun günlük hayatının tümünü ifşa eden, süreklilik taşıyan

1 SERÇEMELİ, Ceyhun, “Ebeveynlerin Sosyal Medyadaki “Over-Sharenting” Davranışlarının Hukuki Açıdan Değerlendirilmesi", TURAN-SAM Uluslararası Bilimsel Hakemli Dergisi; p-ISSN: 1308-8041, e-ISSN: 1309-4033; Y1l: 2020; Ay: Aralık; Cilt: 12/SONBAHAR, Say1: 48, s. 229- 237, s. 230.

Araştırmada, Instagram adı verilen uygulama içerisinde "okul öncesi" etiketi ile yapılan son 500 paylaşımın 236 adedinde, başka bir deyişle \%47,2' de çocukların yüzlerinin göründüğü tespit edilmiştir. Bu araştırma için bkz. KESİCíOĞLU, Oğuz Serdar, "Instagramda "Okul Öncesi" Etiketiyle Yapılan Paylaşımların İncelenmesi", 6. Uluslararası Okul Öncesi Eğitimi Kongresi Tam Metin Bildiri Kitabı, 30 Aralık 2019, Kars, s. 531- 538, 533; SERÇEMELİ, s. 231. 
bir hal alabilir. Bu noktada doktrinde karşımıza "over-sharenting" kavramı çıkmaktadır. Over- sharenting kavramı ise, ebeveynlerin çocuklarına ilişkin ses ve görüntüleri sıklıkla ve aşırı paylaşmaları halini ifade etmektedir. Her bir paylaşım, çocuğun mahremiyet alanını ihlal etme tehlikesini de arttırmaktadır. İnternet kullanımının yaygınlaşması ile ailelerin çocuklarına yönelik bu paylaşımları da artmaktadır. Hatta aileler, birbirlerinden etkilenerek bunu o denli sıklıkta yapmaktadırlar ki, bu durumun doğurabileceği tehlikeler ihmal edilerek, normal olanın bu olduğu anlayışı yaygınlaşmaktadır. Örneğin aileler; çocukları çıplak iken veya üzerlerinde sadece çamaşırları veya bebek bezleri bulunduğu bir sırada veyahut ağladıkları bir durumdayken görüntülerini çekebilmektedirler ve ileride çocukları utandırabilecek bu nitelikteki hassas içerikleri kamuya açık bir şekilde paylaşabilmektedirler. Bu nesilden önceki hiçbir nesil bu denli geniş bir dijital ayak izi ile yetişmediğinden, ileride bu durumun çocuklar üzerinde yaratabileceği olumsuz etkiler de tam anlamıyla kestirilememektedir. Bu veri ailenin ilk paylaşımdaki amacını aşarak, istenenden çok daha geniş kitlelere ulaşabilir ve viral halini alabilir. Şöyle ki, dijital ortama bir kez verilen veri, kullanıcı tarafından sonradan silinse dahi, bu dijital uygulamaların yapısı ve dahası paylaşmaya ve saklamaya izin veren özellikleri sonucu hiçbir zaman tümüyle ortadan kalkmayabilir. Uzun yıllar sonra dahi, bu paylaşımın yapılması hususunda hiçbir söz hakkı bulunmayan çocuğun karşısına çıkarak, onun kişilik hakkını ihlal edebilir³.

\section{B. SHARENTING SONUCU DOĞABILLECEK HUKUKI PROBLEMLER}

Sharenting sonucu ses ve görüntüsü paylaşllan çocuklar birçok potansiyel tehlike ile karşı karşıya kalmaktadırlar. Çocuğu ait ses veya görüntünün internette paylaşılması sonucu ilk olarak çocuklar istismar tehlikesi altında kalabilirler. Bu istismar; cinsel istismar niteliğinde

3 SERÇEMELİ, s. 232; ÖZDEMİR, Hayrunnisa, “Çocukların Kişisel Verilerinin Sosyal Medya Aracılığıyla İşlenmesi”, Selçuk Hukuk Kongresi 2020 Özel Hukuk Tebliğleri Tam Metin Kitabı, Editörler: UYUMAZ, Alper /AKÇAAL, Mehmet / TÜZEMEN ATIK, Ebru, Nobel Akademik Yayıncılık, s. 303- 328, s. 316. 
olabileceği gibi duygusal, fiziksel veya ekonomik istismar şeklinde de ortaya çıkabilir. UNIFEC'in 2010 yılında “Türkiye'de Çocuk İstismarı ve Aile İçi Şiddet Araştırması Özet Raporu"nda da yer aldığı üzere, Dünya Sağlık Örgütü'nün raporuna göre çocuk istismarı; bir yetişkin -ki çocuğun ailesi de bu kapsama dahildir- bir toplum veya ülke tarafından kasten veya ihmal yoluyla çocuğun sağlığını ve fiziksel gelişimini olumsuz yönde etkileyen davranışlardır". Aile farkında dahi olmaksızın çocuğun ses ve görüntüsünü sosyal medyada paylaşmak suretiyle çocuğun aslında mahremiyet alanını da kamuya açmaktadırlar. Aile her ne kadar bu paylaşımı kapalı hesapları yoluyla, örneğin sadece aile fertlerinin veya yakın aile dostlarının ya da çocuğun sınıf arkadaşlarının bulunduğu bir gruba yapsa dahi, bu istismar tehlikesini tümüyle bertaraf edememektedir. Şöyle ki, sosyal medya uygulamalarında bulunan kopyalama, saklama ve paylaşma imkanları sayesinde kapalı bir gruba gönderilen veri dahi üçüncü kişiler tarafından herkes ile paylaşılabilir. Dahası yapılan araştırmalara ${ }^{5}$ göre istismar vakalarının \%80'inde fail, mağdur çocuğun tanıdığı bir kimse olmaktadır. Duygusal istismar bakımından ise, özellikle kamuya açık olarak yapılan paylaşımlarda üçüncü kişilerin çocuğa ilişkin olumsuz bir tutum içerisinde, onu üzecek veya küçük düşürecek mahiyetteki yorum ve değerlendirmeleri de bir siber zorbalık örneği olarak çocukta psikolojik zarar doğurabilir6.

4 T.C. Başbakanlık Sosyal Hizmetler ve Çocuk Esirgeme Kurumu/ UNIFEC; “Türkiye'de Çocuk İstismarı ve Aile İçi Şiddet Araştırması Özet Raporu”, 2010, https://www.unicef.org/turkey/sites/unicef.org.turkey/files/2019-02/cocukistismari-raporu-tr_1.pdf, (Erişim Tarihi: 24.06.2021), s. 7.

ÇÖPÜR, Mazlum/ ÜNERİ, Özden Şükran/ AYDIN, Erkan/ BAHALI, Mustafa Kayhan/ TANIDIR, Canan/ GÜNEŞ, Hatice/ ERDOĞAN, Ayten, "İstanbul Ili Örnekleminde Çocuk ve Ergen Cinsel Istismarlarının Karakteristik Özellikleri", Anadolu Psikiyatri Dergisi, 2012; Sayı: 13, s. 46-50, s. 49.

UZUN, Sevde, “Velayet Hakkı Bağlamında Çocuğun Görüntüsünün Sosyal Medyada Paylaşılması ve Ortaya Çıkabilecek Hukuki Meseleler", http://humanistburo.org/dosyalar/humdosya/Cocugun\%20Goruntusunun\%20Sosy al\%20Medyada\%20Paylasilmasina\%20Dair\%20Hukuki\%20Meseleler\%20(S.Uzun). pdf, (Erişim Tarihi: 22.06.2021), s. 10, 11. 
Sharenting eyleminin bir diğer sakıncası, çocuğa ait görüntü ve sesin özellikle çocuklara ilişkin etiketler ile sosyal medya hesaplarına yüklenmesi halinde, bunun pedofili veya çocuk pornografisine ilişkin olarak kullanılabilmesidir. Örneğin, Kanada Çocuk Koruma Merkezi ${ }^{7}$ ve Avusturalya Çocuk E- Koruma Komiseri ${ }^{8}$, çocukların jimnastik yaparken veya sosyal medya sitesinde modellik yaparken çekilen fotoğraflarının, pornografik amaçlarla kullanılabildiği hususunda aileleri uyarmışlardır. Bir diğer olayda bir büyük anne ve büyük baba, torunlarının fotoğrafını kamuya açık şekilde Facebook'a yüklemişler, bir süre sonra çocuğun annesi bu fotoğrafın pedofili ile ilintili bir sayfada yer aldığını tespit etmiştir9.

Sharenting sonucunda çocuğun paylaşılan sesi veya görüntüsü, üçüncü kişiler tarafından kopyalanabilmekte, bir başka deyişle çalınabilmekte, bu veriler üzerinde değişiklik yapılarak veya değişiklik yapılmaksızın başka mecralarda yayınlanabilmektedir. Hatta bu verileri izinsiz olarak kopyalayan kişiler, çocuklar ile ilgili içeriklerin daha çok rağbet gördüğü sosyal medya ortamlarına girerek, adeta ses ve görüntüsünü kopyaladıkları çocukların ebeveynleri gibi davranabilmektedirler. Bu sayede tanınır olmaya ve gelir elde etmeye çalışmaktadırlar. Teknoloji, internet ve sosyal medyanın gelişimi ile ortaya çıkan bu yeni ihlal türüne literatürde "dijital kidnapping" yani"

KIRKEY, Shirley, “Do You Know Where Your Child's İmage İs? Pedophiles Sharing Photos From Parents' Social Media Accounts", https://nationalpost.com/news/canada/photos-shared-on-pedophile-sites-takenfrom-parents-social-media-accounts, (Erişim Tarihi: 24.06.2021).

BATTERSBY, Lucy, “Millions Of Social Media Photos Found On Child Exploitation Sharing Sites", https://www.smh.com.au/national/millions-of-social-media-photosfound-on-child-exploitation-sharing-sites-20150929-gjxe55.html, (Erişim Tarihi: 24.06.2021).

9 The Telegraph, “Parents discover children's Facebook photos on Russian paedophile website", 13.01.2015, https://www.telegraph.co.uk/news/uknews/crime/11342175/Parents-discoverchildrens- Facebook-photos-on-Russian-paedophile-website.html, (Erişim Tarihi: 24.06.2021); YAVUZ, Can, "Sosyal Medya Ebeveynliği ve Çocukların Unutulma Hakkı", İzmir Barosu Dergisi, Ocak 2020, s. 15-51, s. 25. 
dijital çocuk kaçırma" denilmektedir ${ }^{10}$. Bu, son yıllarda hızla çoğalan ve çocukları hedef alan bir kimlik hırsızlı̆̆ı yöntemidir. Bu yöntemde, çocukların fotoğrafları kullanılarak tümüyle yeni kimlikler yaratılmaya çalışılmaktadır. Özellikle okul yılı başlangıcında birçok aile çocuğunun tam adı, gittiği okul, sınıf, öğretmeni açık olacak şekilde veya ev kapısı önünde evin, sokağın numarası ve adı belli olacak şekilde paylaşım yapabilmektedir. Tüm bu veriler dijital çocuk kaçırma faillerinin çocuğun kim olduğunu ve nerede yaşadığını tespit edebilmesini kolaylaştıran ve çocuğu savunmasız birakan hallerdiri1.

Sharenting eyleminin yaygınlaşması ile çocukların karşılaşabilecekleri bir diğer hukuki sorun ise, internete yüklenen çocuk fotoğraflarının yüz tanıma sistemleri tarafından, ara yüzü geliştirmek için kullanılmasıdır. Ailelerin gizli hesaplarına yükledikleri fotoğraflar dahi, izinsiz olarak yüz tanıma sistemlerinin geliştirilmesini sağlamak amacıyla kullanılabilmektedir. Bu çerçevede Flickr isimli fotoğraf sitesine yıllar önce yüklenen pek çok fotoğrafın MegaFace veri bankasında kullanıldığı ileri sürülmektediri2.

\section{ANA- BABANIN VELAYET HAKKI ve SINIRLARI}

\section{A. VELAYET HAKKININ KAPSAMI}

Velayet hakkı, Türk Medeni Kanunu md 335 vd hükümlerinde düzenlenmektedir. Velayet; ana ve babanın çocuğun sağlıklı gelişimi, bakımı ve eğitimi için gerekli kararları alıp uygulamasını, çocuğun mallarının yönetilmesini ve temsilini içeren haklar ve yükümlülüklerin tümünü kapsamaktadır. Velayet hakkının temelinde çocuğun maddi ve

UZUN, s. 10, 11.

11 BEARAK, Steven, “Digital Kidnapping: What It Is and How to Keep Your Kids Safe on Social Media, Digital kidnapping is growing rapidly, here's what you need to know", https://www.parentmap.com/article/kidnappers-kids-photos-digitalkidnapping-social-media, (Erişim Tarihi: 24.06.2021).

HILL, Kashmir/ KROLIK, Aaron, "How Photos of Your Kids Are Powering Surveillance Technology, Millions of Flickr images were sucked into a database called MegaFace. Now some of those faces may have the ability to sue.", https://www.nytimes.com/interactive/2019/10/11/technology/flickr-facialrecognition.html, (Erişim Tarihi: 24.06.2021); YAVUZ, s. 20- 25. 
manevi varlığının korunması yatmaktadır. Velayet hakkının kapsamını düzenleyen TMK md 339 hükmünde de ana ve babanın çocuğun bakımı ve eğitimi konusunda onun menfaatini nazara alarak karar vermeleri gerekliliği yer almaktadır. Bu bağlamda velayet hem bir hak hem de yükümlülüktür ${ }^{13}$. Velayet ana babanın çocuğun hayatını tümüyle otoriter bir şekilde yönetmesi değil, çocuğu bireyselleşmesi yolunda yönlendirmesidir. Bu çerçevede ana baba, çocuğun yaşına, ayırt etme gücüne göre karar almasına izin vermeli ve bu kararlara saygı duymalıdırlar. Önemli konularda çocuğun da fikri alınmalıdır.

Ana baba, velayet hakkını kullanırken, temel hedef çocuğun üstün yararının gözetilmesi ve korunmasıdır. Çocuğun korunması; çocuk mallarının ve daha da önemlisi çocuğun kişiliğinin korunmasıdır. Ana baba ve çocuk arasındaki ilişkide, taraflar eşit konumda değerlendirilmelidir. Başka bir deyişle çocuğun kişilik hakkı da ana babanın kişilik hakkı ile eş değerdedir. Fakat çocuk, zihinsel, fiziksel, sosyal ve ekonomik durumu gereği korunmaya ve eğitilmeye muhtaç bir

SEROZAN, Rona, Çocuk Hukuku, İstanbul, 2005, s. 250; AKYÜZ, Emine, Ulusal ve Uluslararası Hukukta Çocuğun Haklarının ve Güvenliğinin Korunması, Ankara, 2000, s. 236; AKYÜZ, Emine, Çocuk Hukuku, Çocukların Hakları ve Korunması, Ankara, 2016, s. 223; GÜLTEKİN, Esra, "Çocuğun Kişilik Hakkının Ana-Baba Tarafından Sosyal Medya Aracılığıyla İhlalinin Hukuki Görünümü", Çocuk ve Medeniyet, Say1: 1, 2018, s. 103- 143, s. 108, 109; UZUN, s. 1-2; ÖZTAN, Bilge, Aile Hukuku, Ankara 2015, s.1074, 1075; DURAL, Mustafa/ ÖĞÜZ, Tufan/ GÜMÜŞ, M. Alper, Türk Özel Hukuku, Cilt III Aile Hukuku, İstanbul 2018, s. 354; AKINTÜRK, Turgut/ ATEŞ KARAMAN, Derya, Aile Hukuku, İstanbul, 2016, s. 406. Eskiden daha otoriter bir yapı olarak görülen velayet hakkı kavramı, zaman içerisinde sosyal yapının gelişmesi ile değişime uğramıştır. Bu değişim velayete ilişkin kavramların da değişmesine yol açmıştır. Değişen sosyal yapı içerisinde çocuklar, artık korunması gereken, kendilerine ait duygu ve düşünceleri olan, olgunluğu ölçüsünde kendi hayatı üzerinde söz hakkı bulunan, düşünce ve kararlarına değer verilen birer birey olarak kabul edilmektedir. Bu değişimin bir görünümü olarak Alman hukukunda önceleri velayete karşılık olarak kullanılan ve ebeveyn otoritesi olarak çevrilebilecek "elterliche Gewalt" kavramı, ana babanın bakım ve gözetim yükümlülüğüne işaret eder şekilde "elterliche Sorge" olarak değiştirilmiştir. Benzer bir yaklaşım İngiliz hukukunda da ifadesini bulmaktadır. Çocuk Kanunu'nda önceleri ana bananın hak ve yükümlülüklerine vurgu yapacak şekilde "parental rights and duties" olan kavram, odağı çocuklara çevrilerek "responsibility of children" olarak değiştirilmiştir. GÜLTEKİN, s. 108. 
bireydir. Özellikle küçük çocuklar, kendi hak ve menfaatlerini tek başlarına koruyamazlar. Bu sebeple ana babanın velayetin getirdiği yükümlülükler kapsamında çocuğu korumaları gerekirir. Ancak zaman zaman çocuğun hakları ile ana babanın hakları çatışabilir. Bunun en tipik örneklerinden biri sharenting halinde ortaya çıkmaktadır. Ana babaların bu paylaşma davranışının altındaki saikin, ebeveyn olarak kendilerini ifade etme yolu olduğu ileri sürülmektedir ${ }^{15}$. Fakat bu paylaşma davranışının istismar halini alması durumunda, çocuk doğasının getirdiği zayıf yapısı sebebiyle ana baba tarafından gerçekleştirilen bu istismarla mücadele edebilecek durumda değildir. Bu durumda ana babanın velayet hakkının sınırlandırılması gündeme gelir.

\section{B. VELAYET HAKKININ SINIRLARI}

\section{GENEL OLARAK}

Velayet, ana baba bakımından hem hak hem de yükümlülüktür. TMK md 339 gereği ana baba, çocuğun eğitimi ve bakımı için onun menfaatine olacak karar ve önlemleri alırlar ve uygularlar ${ }^{16}$. Velayet hakk1 kapsamında çocuk, ana babanın sözünü dinlemek yükümlülüğü altındadırlar. Buna karşılık ana baba da önemli konularda olgunluğu ölçüsünde çocuğun da fikrini almalı ve karar alırken bu fikri de göz önünde bulundurmalıdır. Velayet, yapısı gereği ana babaya geniş haklar sağlasa dahi, bu hakların sınırı çocuğun menfaatidir ${ }^{17}$. Ana baba çocuğa

14 İMAMOĞLU, Hülya, “Çocuğun Kişiliğinin Ana Babaya Karşı Korunması, Ankara Üniversitesi Hukuk Fakültesi Dergisi, Ankara, 2005, Cilt: 4, Sayı: 2, s. 183- 218, 191; GİRGİN, Ömer Ali/ GÖNAL, Seray, “Çocuğun Kişisel Verilerinin Sosyal Medyada Ebeveyn Tarafından Paylaşılmasının Hukuki Sonuçları", Türkiye Adalet Akademisi Dergisi, Say1: 44, Ankara, 2020, s. 99- 128, s. 109.

SERÇEMELI, s. 230.

16 AKYÜZ, Emine, "Velâyet ve Çocuğun Korunması", Prof. Dr. Ali Naim İnan'a Armağan, Editörler: ÜNAL, Mehmet/ BAŞPINAR, Veysel/ OZANOĞLU, Hasan Seçkin Ozanoğlu/ YILMAZ, Süleyman, Ankara, 2009, s. 111- 156, s. 116.

ELÇİN, Evgen Gülçin, “Çocuğun Menfaati Gereği Çocukla İlgili Uyuşmazlıklarda Görüşünün Alınmaması Gereken Durumlar", Çocuk Hakları Çalışmaları I, Editörler: ELÇİN, Evgen Gülçin/ GENÇ ARIDEMİR, Arzu, İstanbul, 2017, s. 1- 26, s. 8. 
ilişkin karar alırken çocuğun üstün menfaatini ve çocuğun kişilik hakkını gözetmelidir. Bunlar ana babanın velayet hakkının sınırlarını oluşturmaktadır.

\section{2. ÇOCUĞUN ÜSTÜN YARARI}

Ana baba velayet hakkı kapsamında çocuk ile ilgili kararlar alırken, çocuğun üstün yararı çerçevesinde hareket etmelidir. Çocuğun üstün yararı hem velayete ilişkin konularda hem de çocuğun korunmasına ilişkin durumlarda başvurulması gereken temel unsurdur. Çocuğun üstün yararı kavramı, ulusal ve uluslararası metinlerde yer almasına rağmen açık bir şekilde tanımlanmamıştır; ancak bu durum, bilinçli bir tercihin sonucudur. Tüm dünyada her çocuk için aynı şekilde geçerli olabilecek bir üstün yarar tanımı vermek mümkün değildir. Üstün yarar ilkesinin her somut olay bakımından değerlendirilmesi gerekir. BMÇHS md 3 gereğince çocuk ile ilgili tüm işlemlerde çocuğun üstün yararı öncelikli olarak göz önünde bulundurulmalıdır. Yine BMÇHS md 18 gereği, anne baba çocuğu yetiştirirken çocuğun üstün yararını dikkate almalıdır ${ }^{18}$.

Çocuğun üstün yararı ilkesi; çocukla ilgili bir karar alınacağı zaman çocuğun bedensel, ahlaki, psikolojik, sosyal, ekonomik ve hukuki yönlerden sağlıklı ve dengeli bir biçimde gelişimine olanak sağlayan seçeneklerin tercih edilmesi anlamına gelir. Buna karar verilirken çocuğun doğası, yaşı, durumu, ilgi alanları dikkate alınmalı ve eğer kendisinin bir seçim hakkı olsaydı ortalama, makul bir insan olarak kendi yararı için hangi kararı verecekse ona göre davranılmalıdır ${ }^{19}$.

UZUN, s. 2,3.

19 YÜKSEL, Sera Reyhani; Velayet Hakkının Anayasal Sınırları, İstanbul, 2016, s. 91; ELÇİN GRASSINGER, E. Gülçin, “Çocuğun Menfaati Gereği Görüşünün Alınmaması Gereken Durumlar", Prof. Dr. Rona Serozan'a Armağan, Cilt I, Editör: ENGİN, Baki İlkay, İstanbul, 2010, s. 823- 846, s. 827; AKKURT, Sinan Sami, "Çocuğun Kişiliğinin Korunması ve Velâyetin Belirlenmesinde Çocuğun Menfaati Olgusu", Prof. Dr. Rona Serozan'a Armağan, Cilt I, Editör: ENGİN, Baki İlkay, İstanbul, 2010, s. 91- 120, s. 114, 115; UZUN, s. 2, 3. 
TMK md 339 ve BMÇHS md 12'ye göre, çocuğun menfaatine olan konu hakkında karar verilirken kararlarının doğurabileceği sonuçları kavrayabilecek yetkinliğe sahipse, çocuğun olgunluğu ölçüsünde onun da görüşüne başvurulmalıdır. Bu sebeple sosyal medya hesaplarında çocuk ile ilgili bir tasarrufta bulunulacağı zaman çocuğun zihinsel yetisi bu konuyu ve sonuçlarını anlayabilecek duruma geldiğinde çocuğun da fikri alınarak ve görüşü sorularak, kişilik hakkını ihlal etmeyecek nitelikte bir paylaşım yapılması, çocuğun üstün yararı açısından daha yerinde olur. Ana baba çocuğun ses ve görüntüsünü sosyal medyada paylaşmadan önce, bu paylaşımın çocuğun üstün yararına uygun olup olmadığını göz önünde bulundurmalıdır.

Çocuğun üstün yararı ilkesinin hukuk evreninde yarattığı en önemli işlev, ana babanın velayet hakkını çocuk hilafına kullanarak çocuğa zarar verdiği hallerde, velayet hakkına hukuken yapilabilecek müdahalelerin kapısını açabilmesidir ${ }^{20}$.

\section{3. ÇOCUĞUN KIŞİLIK HAKKI ve MAHREMIYETI}

TMK md 28' de yer alan düzenlemeye göre çocuğun kişilik hakkı, sağ ve tam doğum ile başlar. Kişilik hakkı, bir kişinin toplum içerisindeki saygınlığını tesis eden varlıkların tümü üzerindeki hakimiyettir. Kişilik hakkı; mutlak, para ile ölçülemeyen, devredilemez, kişiye sıkı sıkıya bağlı ve bir ihlale uğraması halinde herkese karşı ileri sürülebilen bir haktır ${ }^{21}$. Kişilik hakkı bakımından çocuğun ana babası da üçüncü kişi niteliğindedir22. Çocuğa ilişkin kararların alınmasında ve çocuğun menfaatinin gözetilmesinde ana baba asli görevlidir. Zorunlu haller haricinde, çocuğun kişilik hakkına müdahale edilemez. Bu noktada

20 ELÇiN GRASSINGER, Gülçin; Türk Medeni Kanununda Yer Alan Velayet Hükümleri Kapsamında Küçüğün Kişi Varlığının Korunması İçin Alınacak Tedbirler (MK md.346, md. 347, md.348), İstanbul, 2009, s. 65.

21 OĞUZMAN, Kemal/ SELIÇİ, Özer/ OKTAY-ÖZDEMİ, Saibe; Kişiler Hukuku (Gerçek ve Tüzel Kişiler), İstanbul, 2012, s. 154, 155, 156.

22 SCHIMKE, Anna, "Rechtliche Rahmenbedingungen der Veröffentlichung von Kinderfotos im Netz durch Eltern", Neue Zeitschrift Für Familienrecht, Sayı: 19, 2019, s. 851-858, s. 857; GÜLTEKİN, s. 112, 113. 
çocuğun kişilik hakkı ancak, onun menfaatinin gerektirdiği hallerde sinırlanabilir ${ }^{23}$. Örneğin çocuk sosyal medya hesaplarında kendisi farkında olmaksızın kişilik hakkını zedeleyebilecek paylaşımlarda bulunuyorsa, ana baba çocuğun menfaati gereği velayet hakkı kapsamında bu paylaşımı durdurmalı ve sona erdirmelidir.

Sosyal medya aracılığıyla ana baba çocuğun kişilik hakkını zedeleyebilecek nitelikte paylaşımda bulunurlarsa, bu takdirde çocuğun kişilik hakkı ana babanın velayet hakkının sınırını oluşturur. Ana babanın, çocuğun üzerinde sahip oldukları hakları, çocuğun menfaatine aykırı olacak şekilde kullanmaları velayet hakkına yapılacak hukuki müdahalelerin gerekçesini oluşturabilir ${ }^{24}$. Kişilik hakkına müdahalenin varlığının belirlenmesi bakımından rıza hayati bir rol oynamaktadır. Çünkü rıza, TMK md 24 gereği müdahalenin hukuka aykırılığını ortadan kaldıran hukuka uygunluk sebeplerinden biridir ${ }^{25}$. Bu rizanın hukuka aykırılığı ortadan kaldırabilmesi için geçerli bir rıza niteliği taşıması gerekir. TMK md 15'e göre ayırt etme gücüne sahip olmayan bir kişinin rızası geçerli değildir. Ayırt etme gücü, bir kişinin hareketlerinin veya kararlarının sonuçlarını doğru bir şekilde kavrayabilmesi anlamına gelir. Her somut olay bakımından çocuğun ayırt etme gücünün varlığı değerlendirilmelidir. Ayırt etme gücünün varlığı için bilinçli bir irade ve bu iradeye uygun davranabilme yeteneği aranır ${ }^{26}$. Çocuğun geçerli bir rıza verdiğinin kabul edilebilmesi için, sosyal medyada hakkında paylaşım yapılmasına bilinçli bir şekilde iradesiyle olumlu yanıt vermesi gerekir. TMK md 339 ve BMÇHS md 12 gereği de çocuğun belli bir akli olgunluğa ulaştı̆̆ı hallerde, onu da ilgilendiren hususlarda görüşü alınmalıdır. Rıza açık veya örtülü olarak verilebilir. Ayırt etme gücüne sahip olmayan bir çocuğun, sosyal medyada hakkında paylaşım

\footnotetext{
23 İMAMOĞLU, s. 192, 193.

24 ELÇİN GRASSINGER, Velayet, s. 65; İMAMOĞLU, s. 194.

25 OĞUZMAN/ SELIÇİ/ OKTAY-ÖZDEMİR, s. 189.

26 OĞUZMAN/ SELIÇİ/ OKTAY-ÖZDEMİ,, s. 52, 53; HONSELL, Heinrich/ VOGT, Nedim Peter/ GEISER, Thomas, Basler Kommentar, Zivilgesetsbuch I, Basel- GenfMünchen, 2010, Art 16, N. 3, 10, 13.
} 
yapılmasına ilişkin verdiği rıza, tam ehliyetsiz olduğundan dolayı geçerli değildir. Bu noktada yasal temsilci olan ana babanın rızası, kural olarak müdahaleye maruz kalan kişinin rızasının yerine geçemez ${ }^{27}$. Özellikle de müdahaleye sebep olan kişinin ana baba olması halinde, verdikleri rıza geçerli bir nitelik taşımamaktadır ${ }^{28}$. Ayırt etme gücü bulunan çocuklar ise, sınırlı ehliyetsizdirler. Sınırlı ehliyetsizler, TMK md 16 gereğince yasal temsilcilerinin rızası olmadan kendi işlemleri ile borç altına giremezler. Velayet hakkına sahip ana baba, rızayı birlikte vermelidir ${ }^{29}$. TMK md 16/I'e göre sınırlı ehliyetsizler, kişiye sıkı sıkıya bağlı haklarını, yasal temsilcilerinin rızası olmadan kullanabilirler. BMÇHS md 12'ye göre, ayırt etme gücüne sahip küçüklerin, kendilerini ifade etme hakları da kişiye sıkı sıkıya bağlı haklar içerisinde kabul edilmektedir ${ }^{30}$. Sınırlı ehliyetsizler, kişiye sıkı sıkıya bağlı olan hakları kendi başlarına kullanabilirler ${ }^{31}$. Bu çerçevede ayırt etme gücü olan sınırlı ehliyetsiz bir

27 OĞUZMAN/ SELİÇ்/ OKTAY-ÖZDEMİ, s. 81, 82, 195; FANKHAUSER, Roland / FISCHER, Nadja, “Kinderfotos auf Facebook oder wenn Eltern die Persönlichkeitsrechte ihrer Kinder verletzen", Brennpunkt Familienrecht, Festschrift für Thomas Geiser zum 65. Geburtstag, Editörler: FANKHAUSER, Roland/ REUSSER, Ruth E./ SCHWANDER, Ivo, Zürich, 2017, s. 193- 215, s. 200, 201. Kural olarak kişiye sıkı sıkıya bağlı haklar bizzat hak sahibi tarafından kullanılmalıdır. Bu hakların yasal temsilci tarafından kullanılamayacağı kabul edilmektedir. Fakat kişiye sıkı sıkıya bağlı hakların tam ehliyetsizler tarafından hiçbir şekilde kullanılamaması bazı hallerde hakkaniyete aykırı sonuçlar doğurabilmektedir. Bu sebeple HONSER/ VOGT/ GEISER kişiye sıkı sıkıya bağlı hakların ikiye ayrılarak incelenmesinin daha doğru olacağını savunmaktadır. Bu ikili ayrıma göre mutlak haklar bakımından yasal temsilcinin yetkisi yokken, nispi haklar bakımından ise yasal temsilin kabul edilmesi gerekir. Kanaatimizce sosyal medyada kişilik hakkının korunması talebi de, nispi anlamda kişilik hakkı olarak kabul edilmelidir. Ayrıntılı bilgi için bkz. HONSER/ VOGT/ GEISER, Art 18, N 15, 15a, Art 19, N 40, 41.

DURAL, Mustafa/ ÖĞÜZ, Tufan, Türk Özel Hukuku Cilt II Kişiler Hukuku. İstanbul, 2017, s. 149.

OĞUZMAN/ SELİÇ்̇/ OKTAY-ÖZDEMİ, s.86- 89;

OĞUZMAN/ SELIÇ̇̇/ OKTAY-ÖZDEMIR, s. 97; SEROZAN, Rona, Medeni Hukuk, İstanbul, 2011, s. 402- 408. Bucher, bu hakkın Anayasa'dan temellendiğini savunmaktadır. Ayrıntılı bilgi için bkz. BUCHER, Andreas, Natürliche Personen und Personlichkeitschutz, Basel, 2009, N. 157. 
çocuk hakkında sosyal medyada ses ve görüntü paylaşımı yapılmadan evvel, çocuğun rızası alınmalıdır ${ }^{32}$. Çocuk, bu paylaşıma rıza vermediğinde, ana babanın bu paylaşımı yapma hakkı yoktur. Ana baba tarafından, çocuğun kişilik hakkı zarara uğratıldığında, çocuk yasal temsilcisi konumundaki ana babasına dava açarak bu sosyal medya paylaşımının yapılmamasını, hali hazırda yapılmışsa durdurulmasını ve kaldırılmasını talep edebilir. Bu noktada kişilik hakkının korunması için harekete geçen çocuk, yasal temsilcisinin onayına tabi değildir. $\mathrm{Bu}$ konuya örnek teşkil edebilecek bir olayda İtalya' da 16 yaşındaki bir genç, annesine karşı rızası olmadan fotoğraflarını paylaştığı gerekçesiyle açtığı davayı kazanmıştır. İtalyan mahkemeleri, annenin çocuğun fotoğraflarını sosyal medyadan kaldırmaması veya gelecekte de aynı şekilde fotoğraf paylaşması halinde 10 bin Euro ödemesine karar vermişlerdir ${ }^{33}$. Türk hukukunda bu konu ile ilgili bir kararda ise, Instagram hesabından sürekli olarak çocuklarının fotoğrafını paylaşan bir anneye karşı, baba açtı̆̆ı davada çocukların reklam malzemesi yapıldığını ve bu paylaşımların çocukların istismarına davetiye çıkardığı gerekçesiyle velayetin kendisine verilmesini talep etmiştir. Ara kararda mahkeme, dava bitene kadar çocukların velayetini babaya bırakmış ve annenin de sosyal medya hesaplarından çocuklara ilişkin fotoğraf paylaşmasını yasaklamıştır. Mahkeme, dava süreci sonunda pedagog görüşlerine

32 Alman hukukuna göre bu rızanın geçerli olarak verildiğinin kabul edilebilmesi için çocuk en az 14 yaşında olmalıdır. SCHIMKE, s. 855. 04.05.2016 Tarih ve L 119 sayılı Avrupa Birliği Resmi Gazetesi sayfa 1-88'de yayımlanan 2016/679 sayılı Avrupa Birliği Veri Koruma Tüzüğü md 8 ise, çocuğun bilgi toplumu hizmetlerine ilişkin rızasının geçerli kabul edilebilmesi için en az 16 yaşında olmasını aramaktadır. 16 yaşından küçük çocuklar için velayet hakkı sahibinin rıza verebileceği öngörülmüştür. Yine tüzüğe göre üye devletler rıza bakımından 13 yaşın altında kalan bir ölçü kabul edemezler.

33 https://www.haberturk.com/italyada-cocugun-fotografini-paylasan-anneye-ceza1788741; https://www.bbc.com/turkce/haberler-dunya-42604622, (Erişim Tarihi: 25.06.2021). 
dayanarak çocukların velayetinin annesinde kalmasına, ancak paylaşımlara dair yasaklamanın devamına karar vermiştir ${ }^{34}$.

\section{VELAYET HAKKI İLE ÇOCUĞUN MENFAATLERINIIN YARIŞMASI}

Sosyal medya hesaplarında çocuklarına ilişkin ses ve görüntü paylaşan ana babaların, ifade özgürlüklerini kullandıkları, kendi duygu ve düşüncelerini paylaşmak amacıyla hareket ettikleri ileri sürülmektedir. Bu yaklaşıma göre ana babanın yaptığı paylaşımın ifade özgürlüğü alanına girip girmediğinin değerlendirilmesi gerekir ${ }^{35}$. Ana babalar, bu paylaşımlar vasıtasıyla kendileri ile benzer durumda olan ailelere ulaşma ve onlarla iletişim kurma, başka bir deyişle dayanışma imkânı elde etme amacı da taşıyabilmektedirler. Ayrıca çocukları ilgilendiren alanlarda profesyonel olarak çalışan akademisyen, hekim, ebe, hemşire, beslenme uzmanı, psikolog, çocuk gelişim uzmanı gibi meslekler icra eden ana babalar da kendi çocuklarını veya kendilerinden uzmanlıkları ile ilgili konularda hizmet alan çocukları, örnek olması amaciyla, adeta bir ekran yüzü olarak kullanabilmektedirler. Bu paylaşımlar, kamuya yararlı bir faaliyet yürütmek amacıyla yapılsa dahi üstün kamu yararı ile çocuğun menfaatlerinin çatışması durumunda hangisine öncelik verilmesi gerektiği sorunu ortaya çıkmaktadır. Bunun yanı sıra bazı ana babalar da bu sosyal medya araçları sayesinde, çocukları vasıtasıyla reklam iştirakleri kurarak gelir elde etmektedirler. Tüm bu örnekler, paylaşım yapan ana babanın menfaatleri ile çocuğun menfaatlerinin çatışması sonucunu doğurmaktadır.

Velayet hakkı kapsamında, ana baba, çocuğun eğitimi, yaşamı, gelişimi için gerekli kararları almak ve uygulamak yükümlülüğü

\footnotetext{
34 https:/www.gazeteduvar.com.tr/turkiye/2017/06/30/cocuklariyla-takipci-kazandivelayet-gitti, (Erişim Tarihi: 25.06.2021); https://www.cnnturk.com/turkiye/bloggeranneye-cocuk-istismari-suclamasi-mahkeme-fotograflari-yasakladi?page $=4$, (Erişim Tarihi: 25.06.2021); https://www.cumhuriyet.com.tr/haber/pedagog-gorusu-davaseyrini-degistirdi-mahkemeden-bloger-anneyi-sevindiren-karar-788721, (Erişim Tarihi: 25.06.2021).
}

UZUN, s. 4. 
altındadır. Bazı hallerde velayet hakkı kullanımı, çocuğun kişilik hakkı ile çatışabilir ve bu hallerde müdahale çocuğun üstün yararı sebebiyle hukuka uygun nitelik taşır. Örneğin, çocuğun, sosyal medyada, kendi kişilik hakkını zedeleyecek nitelikte paylaşım yapması halinde, ana baba çocuğun bu paylaşımına engel olabilir veya paylaşımı kaldırabilir. Kural olarak bu, çocuğun kişilik hakkına yönelik bir müdahale olsa dahi, amaç çocuğun üstün yararını korumak olduğundan, hukuka uygundur ${ }^{36}$.

Ana babanın velayet hakkına dayanarak çocuğun ses ve görüntüsünü paylaşması durumunda ana babanın ifade özgürlüğü ile çocuğun üstün menfaati arasında bir çatışma ortaya çıkabilmektedir. Anayasa md 26 ve Avrupa İnsan Hakları Sözleşmesi md 10 kapsamında, kişinin düşünce ve ifade özgürlüğü koruma altına alınmıştır. İfade özgürlüğü ancak kanunlar ile meşru bir amaç doğrultusunda ve demokratik toplumun gereklerine uygun olarak sinırlandırılabilir ${ }^{37}$. AİHS md 10/2'e göre ifade özgürlügünü sınırlamanın meşru amaçlarından biri de başkalarının şöhretinin ve haklarının korunmasıdır ${ }^{38}$. Velayet hakkının sınırları içerisinde kaldığını düşünerek paylaşım yapan ana babalar, çocuğun kişilik hakkını ihlal etmemelidir. Ana babanın ifade özgürlüğü ile çocuğun kişilik hakkı ve üstün yararı çatıştığında, çocuğun üstün yararına öncelik verilmelidir. Başka bir deyişle ana babanın sosyal medya paylaşımlarındaki ifade özgürlüğünün sınırı çocuğun kişilik hakkı ve üstün yararı ilkesidir ${ }^{39}$. Bu paylaşımlar sırasında örneğin bir rahatsızlığa sahip olan çocuk hakkındaki tüm kişisel

36 GÖRGEÇ, Başak, Türk Medeni Kanunu'nda Velayet Hükümleri ve Özellikle Çocuğun Korunması, Yayınlanmamış Yüksek Lisans Tezi, İstanbul, 2011, s. 30; UZUN, s. 4.

37 TEZİÇ, Erdoğan, Anayasa Hukuku, İstanbul, 2017, s. 203; ÖZBUDUN, Ergun, Türk Anayasa Hukuku, Ankara, 2010, s. 114; ÖZBEY, Özcan, “Avrupa İnsan Hakları Sözleşmesi Işığında İfade Özgürlüğü Kısıtlamaları”, TBB Dergisi, Sayı: 106, 2013, s. 41- 92, s. 49- 60; KARAN, Ulaş, İfade Özgürlüğü, Anayasa Mahkemesine Bireysel Başvuru El Kitapları Serisi - 2, Avrupa Konseyi, Strasbourg Cedex- Ankara, 2018, s. 101 vd; GÜLTEKİN, s. 117.

ÖZBEY, s. 76- 80 . 
sağlık verileri, çocuğun tanınmasına imkân verilecek şekilde paylaşılmaktadır. Çocuğun ileride kendisi hakkında paylaşımda bulunulmasını istemeyeceği hususlarda, ana babanın veya uzmanların paylaşım yapmaması gerekir. Aksi takdirde, bu durum çocuğun kişilik hakkının bir diğer ihlalidir. Özellikle sağlık verileri, kişiye ilişkin hassas veriler niteliğinde olduğundan Kişisel Verilerin Korunması Kanunu md 7 ve Hasta Hakları Yönetmeliği md 23 gereği bunların anonimleştirilmesine, çocuğun tanınmasına yol açacak hiçbir detayın paylaşılmamasına özen gösterilmelidir. Verinin anonimleştirilmemesi, somut olayın özelliklerine göre aynı zamanda hekimin sır saklama yükümlülügünün ihlali niteliği de taşıyabilir ${ }^{40}$. Özellikle alanında uzman olan kişilerin, benzer durumdaki çocuklar hakkında bilgi vermek amacıyla paylaştıkları çocuğa ait ses ve görüntüler bakımından, üstün kamu yararının söz konusu olup olmadığı, bu bağlamda da kişilik hakkı ihlali bakımından bir hukuka uygunluk sebebi bulunup bulunmayacağ sorunu akla gelmektedir. Bu durum basın yoluyla yapılan kişilik hakkı ihlallerine benzetilebilir. Basın yoluyla yapılan kişilik hakkı ihlalinin hukuka uygun kabul edilebilmesi için yapılan haberin üstün kamu yararı taşıması aranır. Başka bir deyişle, kamunun haber almaya ilişkin yararı, ihlal edilen kişilik hakkından daha üstün olduğu durumda bu bir hukuka uygunluk sebebi oluşturmaktadır ${ }^{41}$. Fakat kişilik hakkı ihlal edilen, kendisini bu şekildeki müdahalelere karşı koruyamayacak durumda olan çocuk olduğu için, çocuğun üstün yararı ilkesi kanaatimizce kamunun üstün yararından daha önemlidir. Bu sebeple kamunun haber alması ve bilgilenmesinden doğan üstün kamu yararı ile çocuğun kişilik hakkı ve

40 DÜLGER, Murat Volkan, “Sağlık Hukukunda Kişisel Verilerin Korunması ve Hasta Mahremiyeti", İstanbul Medipol Üniversitesi Hukuk Fakültesi Dergisi Cilt:1, Sayı: 2, 2015, s. 43-80, s. 51, 59; KANDİLLİ, Elif, Sağl1k Hukukunda Etik Açısından Kişisel Veriler ve Mahremiyet Hakkı, Yayınlanmamış Yüksek Lisans Tezi, İstanbul, 2019, s. $44,45$.

KILIÇOĞLU, Ahmet, “Kişilik Haklarına Basın Yoluyla Saldırılar Bakımından Medeni ve Borçlar Kanunumuzda Yapılan Değişiklikler", TBB Dergisi, Sayı: 3, 1990, s. 371- 400, 381; KILIÇOĞLU, Ahmet, "Basın Özgürlüğünün Suistimali", TBB Dergisi, Sayı: 3-4, 1993, s. 385- 388, s. 386. 
üstün yararı çatıştığında çocuğun korunmasına öncelik verilmeli ve ihlalin gerçekleştiği kabul edilmelidir ${ }^{42}$.

Ana babanın velayet hakkı ile çocuğun haklarının çatıştı̆̆ durum ise çocuğun görüntülerinin metalaştırılması ve gelir elde etmek amacıyla paylaşılmasıdır. Ana babalar, kendi adlarına veya çocuk adına açtıkları sosyal medya hesapları aracılığıyla çocuğun ses ve görüntüsünü paylaşmak suretiyle takipçi sayılarını arttırmaya çalışmaktadırlar ${ }^{43}$. Takipçi sayısının artmasını temin etmek amacıyla bu hesaplar genellikle kamuya açık hale getirilmekte ve isteyen herkes bu verilere kolayca ulaşabilmektedir. Özellikle çocuklar ile ilgili ürünlerini pazarlamaya çalışan şirketler, ana babalar ile reklam sözleşmeleri yapmakta ve çocuğu kullanmak suretiyle ciddi gelir elde edebilmektedirler. Bu durum kendi içerisinde bir kısır döngü meydana getirmektedir. Kullanılan sosyal medya hesabının takipçi sayısı arttıkça daha fazla reklam sözleşmesi gelmekte, yapılan reklam sayısı arttıkça da daha çok takipçi edinilmektedir. Hatta ana babalar beğeni ve yorum sayısını arttırmak, buna bağlı olarak da daha çok iş anlaşması yapabilmek kaygısıyla çocuğa ilişkin giderek daha fazla içerik üretmektedirler ${ }^{44}$. Bu durum çocuğun kişilik hakkını ihlal etmenin yanı sıra çocuğun ekonomik yönden istismar edilmesi sonucunu da doğurabilir. Bu sebeple de ana babanın velayet hakkına hukuki olarak müdahale edilmesinin yolunu açabilir.

42 GÜLTEKİN, s. 122; KARABAĞ BULUT, Nil, “Basın Özgürlüğü ile Özel Yaşama Saygı Gösterilmesi Hakkı Arasında Kurulacak Dengenin, Avrupa İnsan Hakları Mahkemesi'nin von Hannover v. Almanya Vakasına İlişkin 24 Haziran 2004 Tarihli Kararı Işı̆̆ında Değerlendirilmesi", Prof. Dr. Rona Serozan'a Armağan, Cilt: II, İstanbul, 2010, s. 1055-1112, s. 1103.

GİRGİN/GÖNAL, s. 111.

44 GÜLTEKİN, s. 123, 124. 


\section{III. ÇOCUĞUN HAKLARININ SHARENTING SONUCU İHLAL EDİLMESI DURUMUNDA UYGULANABİLECEK ÖZEL HUKUK YAPTIRIMLARI VE ALINABILLECEK ÖNLEMLER}

Anayasa'da, Türk Ceza Kanunu'nda ve Türk Medeni Kanunu'nda çocuk hakları ve çocuğun istismarı konusu çeşitli açılardan düzenlenmiştir. Ancak çalışmamız kapsamında yalnızca özel hukuk bakımından alınabilecek yaptırım ve önlemlere değinilmiştir.

\section{A. UYGULANABİLECEK ÖZEL HUKUK YAPTIRIMLARI}

Ana babanın sharenting eylemi sonucunda çocuğun kişilik hakkının ihlal edilmesi veya çocuğun istismar edilmesi halinde gerekli önlemlerin alınması veya yaptırımların uygulanması talep edilebilir. Her ilgili, çocuğun korunması amacıyla mahkemeden talepte bulunabilir ${ }^{45}$. Ayırt etme gücüne sahip olan çocuk, bu davayı kendisi açabilir. Ayırt etme gücüne sahip olmayan çocuklar bakımından ise, sharenting eyleminde bulunmayan ebeveyn dava açabileceği gibi, her iki ebeveynin de bu ihlali gerçekleştirmesi halinde çocuğa bir kayyım atanarak bu kayyım aracılığıyla dava açılabilir ${ }^{46}$.

Sharenting sonucu kişilik hakkının ihlal edildiği durumda öncelikle TMK md 24 vd ile Türk Borçlar Kanunu md 49 çerçevesinde kişiliği koruyan davalar ve haksız fiil gündeme gelir. TMK md 25 hükmüne göre mahkemeden saldırı tehlikesinin önlenmesi, süren saldırıya son verilmesi, sona eren saldırının da hukuka aykırılığının tespiti talep edilebilir. Hukuka aykırılığın tespiti sonucunda maddi ve manevi tazminat talebi de gündeme gelebilir ${ }^{47}$. Sosyal medya paylaşımı

45 BAYGIN, Cem, Soybağ1 Hukuku, İstanbul, 2010, s. 323; İMAMOĞLU, s. 195; GÜLTEKİN, s. 133, 134, 135.

İMAMOĞLU, 214; OĞUZMAN/ SELİÇİ/OKTAY-ÖZDEMİR, s. 89.

47

ÖZCAN BÜYÜKTANIR, Burcu G., Çocuğun Kişilik Hakkı ve Çocuğun Kişilik hakkının Hukuka Aykırı Fiillere Karşı Korunması, Ankara, 2019, s. 210, 211, 214 vd; DURAK, Yasemin, "İnternet Yoluyla Kişilik Haklarına Saldırı ve Hukuki Koruma", Selçuk Üniversitesi Hukuk Fakültesi Dergisi, Cilt: 22, Sayı: 1, 2014, s. 101- 125, s. 110 vd; AKIPEK, Şebnem, "Özel Hukuk ve İnternet", http://inet- 
aracılığıyla çocuğun kişilik hakkı saldırıya uğradığında, saldırıya son verilmesi kapsamında söz konusu paylaşımların sosyal medya hesaplarından silinmesi, saldırı tehlikesinin önlenmesi çerçevesinde de ileride tekrar böyle bir paylaşım yapılmamasına karar verilmesi talep edilebilir. Ayrıca ana babanın sosyal medya paylaşımı yoluyla yaptığı kişilik hakkı ihlalinin hukuka aykırılığının tespiti de istenebilir. Bunlarla birlikte TMK md 25/II kapsaminda somut olayın özelliklerinin gerektirmesi halinde bu durumun üçüncü kişilere bildirilmesi veya yayınlanması da hükme bağlanabilir.

Maddi tazminat talep edilebilmesi için, haksız fiil sorumluluğunun şartları gerçekleşmiş olmalıdır. Haksız fiil şartları; fiil, hukuka aykırılık, zarar, kusur ve hukuka aykırı fiil ile zarar arasında illiyet bağının bulunmasıdır ${ }^{48}$. Buna göre sosyal medyada geçerli rıza olmaksızın paylaşılmış bir kişisel veri bulunmalıdır. Bu hukuka aykırı bir fiil teşkil eder. Bu paylaşım sonucu çocuğun kişilik hakkı zarara uğramış olmalıdır. Zarar, maddi veya manevi zarar olarak ortaya çıabilir. Maddi zarar, çocuğun malvarlığında iradesi dışında meydana gelen azalmayı ifade eder ${ }^{49}$. Bunun yanı sıra manevi tazminat da talep edilebilir. Çünkü çoğunlukla sharenting eylemi, çocuğun kişilik hakkını ihlal ederek şahıs varlığ 1 değerlerinde objektif bir azalmaya yol açar ve manevi zarara sebep olur $^{50}$. Objektif manevi zarar teorisine göre, kişilik hakkının ihlali başlı

tr.org.tr/inetconf5/tammetin/hukuk.html, (Erişim Tarihi: 14.07.2021); von CAEMMERER, Ernst, “Alman Hukukuna Göre Kişiliğin Özel Hukuk Yönünden Korunması", Çeviren: ÖZSUNAY, Ergun, İstanbul Üniversitesi Mukayeseli Hukuk Araştırmaları Dergisi, Cilt: 7, Sayı: 10, 1973, s. 69- 83, s. 71.

48 EREN, Fikret, Borçlar Hukuku Genel Hükümler, Ankara, 2017, s. 540 vd.

49 Kişilik hakkı veya bu hakkı oluşturan değerler, kural olarak malvarlığı kapsamında değildir. Bununla birlikte kişiliği oluşturan mahremiyet, şeref, ekonomik itibar gibi bazı değerler malvarlığı üzerinde sonuç doğurabilir ve maddi zarar oluşturabilirler. Ayrıntılı bilgi için bkz. EREN, s. 546.

50 EREN, s. 556; KESKİN, Dilşad, Objektif Manevi Zarar Teorisi Açısından Manevi Tazminat, Ankara, 2016, s. 99 vd.; ERLÜLE, Fulya, Bedensel Bütünlügün İhlalinde Manevi Tazminat, Ankara, 2011, s. 42 vd.; ANTALYA, Gökhan, “Manevi Zararın Belirlenmesi ve Manevi Tazminatın Hesaplanması -Türk Hukukuna Manevi Zararın İki Aşamalı Olarak Belirlenmesine İlişkin Bir Model Önerisi- “, Marmara 
başına manevi zararın meydana gelmesi için yeterlidir ${ }^{51}$. Sübjektif teoriye göre ise kişilik hakkının ihlalinin yanı sıra, zarar görenin bu sebeple acı, elem, 1stırap duyması da aranmalıdır ${ }^{52}$. Kanaatimizce manevi tazminat talebi açısından çocuğun kişilik hakkının ihlal edilmesi yeterli kabul edilmelidir. Çocuğun, bu paylaşım sonucunda bir acı, elem duymasının aranmasına gerek yoktur. Bu sayede ayırt etme gücü olmayan çocuğun kişilik hakkı, sosyal medya paylaşımları sonucu ihlal edildiğinde, manevi tazminatın talep şartlarının oluştuğu kabul edilir ve çocuk açısından daha etkin bir koruma sağlanabilir. TMK md 25/ III kapsaminda, ana baba sosyal medyada çocuğun ses ve görüntüsünü reklam aracı olarak gelir elde etmek amacıyla kullanmışsa, kişilik hakkı ihlalinin tespit edilmesi durumunda elde edilen kazancın vekaletsiz iş görme hükümlerine göre iadesi de istenebilir.

Kişilik hakkının bir diğer görünümü olarak unutulma hakkı da talebe konu olabilir. Unutulma hakkı, kişisel verilerin korunması yöntemlerinden biridir. Unutulma hakkı, dijital ortamda yer alan rahatsız edici her türlü kişisel verinin, bu veri sahibinin talebi doğrultusunda bir daha geri getirilemeyecek biçimde silinmesi ve ortadan kaldırılmasıdır ${ }^{53}$. Unutulma hakkı sayesinde, kişiler kendileri hakkında internette yer alan

Üniversitesi Hukuk Fakültesi Hukuk Araştırmaları Dergisi, Sayı: 22, 2016, s. 221-250, s. 226- 231.

EREN, s. 556, 557; KESKİN, s. 103 vd; ERLÜLE, s. 48; ANTALYA, s. 229.

EREN, s. 557, 558; KESKİN, s. 99 vd; ERLÜLE, s. 44; ANTALYA, s. 227. Bunların yanı sıra manevi zarar bakımından bir de karma görüş kabul edilmektedir. Ayrıntılı bilgi için bkz. ANTALYA, s. 229, 230. Fakat bu görüş de temelde sübjektif teoriden ayırt edilmediği için eleştirilmektedir. Ayrıntılı bilgi için bkz. KESKİN, s. 108.

ELMALICA, Hasan, “Bilişim Çağının Ortaya Çıkardığı Temel Bir İnsan Hakkı Olarak Unutulma Hakkı", Ankara Üniversitesi Hukuk Fakültesi Dergisi, Cilt:65, Sayı: 4, 2016, s. 1603-1636, s. 1611; GÜLENER, Serdar, “Dijital Hafızadan Silinmeyi İstemek: Temel Bir İnsan Hakkı Olarak “Unutulma Hakkı”, TBB Dergisi, Sayı:102, 2012, s. 219- 240, s. 226; AKGÜL, Aydın, "Kişisel Verilerin Korunmasında Yeni Bir Hak: “Unutulma Hakkı" ve AB Adalet Divanı'nın "Google Kararı”, TBB Dergisi, Sayı:116, 2015, s. 11- 38, s. 16, 17; YILDIZ, Tuba, Kişilik Hakları Açısından Unutulma Hakkı, Yayınlanmamış Yüksek Lisans Tezi, Ankara, 2019, s. 140- 145; AKYÜZ BİLGE, Canan, Unutulma Hakkı ve Türk Hukuku'ndaki Görünümü, Yüksek Lisans Tezi, Ankara, 2019, s. 78; SERÇEMELİ, S. 234. 
kişisel verilerinin silinmesini ve daha fazla yayılmamasını talep etme imkanına sahiptirler. Bu hakkı ileri süren kişi, artık kendisine ait kişisel verinin izlenememesini amaçlamaktadır. Unutulma hakkı kapsamına kişinin haberi olmadan üçüncü kişiler tarafından yüklenen verilerin yanı sıra kendi rızaları ile verdikleri bilgiler de girmektedir. Unutulma hakkı, kişinin kendisi hakkındaki kişisel veriyi tam anlamıyla kontrol etmesini ve bireyin geçmişini ve geleceğini serbestçe şekillendirme hakkını elinde bulundurmasını sağlamaktadır ${ }^{54}$. Çocuk, ana babası veya üçüncü kişiler tarafından kendisi hakkında dijital ortama yüklenmiş verilerin silinmesini talep edebilir. Bu sayede çocuk, ana babası veya üçüncü kişiler tarafından kendisi hakkında yüklenmiş, onu ayrıştıran, kınanmasına veya aşağılanmasına sebep olan, onu küçük düşüren verilerden tümüyle kurtulabilir. Bu da çocuğa, tabiri caizse hayatta beyaz bir sayfa açma ve temiz bir başlangıç yapma fırsatı vererek ana babası veya üçüncü kişilerin hatalı paylaşımları sebebiyle zarar gören sosyal ve ekonomik dünyasını yeniden şekillendirme yolunu açabilir.

Sharenting sonucu ana babanın karşılaşabileceği bir diğer yaptırım ise velayet hakkı kapsamında ortaya çıkabilir. TMK md 346 kapsamında çocuğun yararı tehlikeye girdiğinde, hâkim öncelikle ana babayı gerekli önlemleri almaları konusunda uyarmalı, eğer onların gücü yetmezse bizzat önlem almalıdır. Çocuğun yararı kavramı, içine bedensel, zihinsel, ruhsal ve maddi gelişimi de alacak şekilde geniş yorumlanmalıdır. Bu önlemleri almak için çocuğun yararının riske girmesi yeterlidir, ana babanın kusurlu davranıp davranmadığına bakılmaz ${ }^{55}$. Çocuğun yararı henüz tehlikeye düşmemiş olsa dahi, bu riskin varlığ 1 halinde hâkim gerekli önlemleri almalıdır ${ }^{56}$. Çocuğun üstün yararını gözetme ve tehlikeye düştüğünde gerekli önlemleri alma yükümlülüğü ilk olarak velayet sahibi ana babadadır. Onlar gerekli önlemleri alamazlar veya aldıkları önlemler yetersiz olursa hâkim, uygun önlemleri almalıdır.

\footnotetext{
54 AKGÜL, s. 17.

55 İMAMOĞLU, s. 194; BAYGIN, s. 318.

56 ELÇİN GRASSINGER, Velayet, s. 51.
} 
Fakat sharenting örneğinde olduğu gibi, eğer çocuğun üstün yararını tehlikeye düşürecek bu ortama, bizzat velayet sahibi ana babası sebep oluyorsa, hâkim beklemeksizin doğrudan kendisi gerekli önlemlere hükmetmelidir. Bu çerçevede hâkim, ana babanın, çocuğun haklarını ihlal eder durumdaki sosyal medya paylaşımlarını durdurmasına, bu paylaşımları kaldırmasına ve bir daha yüklememesine hükmedebilir. Somut olayın koşulları gerektirdiğinde ana babanın sosyal medya okur yazarlığı eğitimi alması, rehberlik ve danışmanlık hizmetlerine gönderilmesi, ailenin denetlenmesi, çocuğa kayyım atanması gibi başka önlemler de alınabilir ${ }^{57}$. Eğer bu önlemler çocuğun yararını korumaya yeterli değilse, çocuğun bedensel, zihinsel gelişimi tehlikede ise veya çocuk manen terk edilmiş durumdaysa, TMK md 347 gereği, hâkim çocuğu ana babasından alarak başka bir aile yanına veya kuruma yerleştirebilir. Kanunkoyucu velayete ilişkin yükümlülüklerin ihlalinden doğan yaptırımları kademeli olarak ağırlaştırmaktadır. TMK md 347'de yer alan önlemin de çocuğu korumaya yetmemesi durumunda son çare olarak, TMK md 348 kapsamında ana babanın velayet hakkı kaldırılır ${ }^{58}$. Bu karar, aksi belirtilmedikçe mevcut ve doğacak tüm çocukları kapsar niteliktedir. TMK md 348 gereği velayet ana babanın her ikisinden birden kaldırılırsa, çocuğa vasi atanır. Çocuk vesayet altındaysa, TMK md 403 hükmü uygulanır. Vasi, görevi gereği çocuğun kişilik hakkı ile malvarlığı ile ilgili tüm işlemlerde küçüğün menfaatini korumalıdır ${ }^{59}$. Eğer vasi görevini gereği gibi yerine getirmezse, hatta yetkilerini kötüye kullanır ve o da çocuğu sosyal medya hesaplarında paylaşmak suretiyle çocuğun kişilik hakkını ve üstün yararını zedelerse, TMK md 483 gereği vesayet makamı tarafından görevinden alınır. 


\section{B. SHARENTING SONUCU ÇOCUĞUN HAKLARININ İHLAL EDİLMEMESİ İÇIN ALINABILLECEK ÖNLEMLER}

Çocuklar ile ilgili paylaşımlarda bulunurken, onların kişilik hakkını ihlal etmemek ve onları istismara açı hale getirmemek amacıyla bazı önlemler alınmalıdır. Çocuk ile ilgili paylaşım yapılırken, yapılan bu paylaşımın çocuğun psikoloji ve gelişimi üzerinde nasıl bir sonuç doğuracağ 1 hesaba katılmalıdır ${ }^{60}$. Bu sebeple çocuğu incitici, çocuğun paylaşılmasını istemeyeceği, utanç verici, onun dışlanmasına neden olabilecek paylaşımlar yapılmamalıdır. Paylaşılan içeriğin, ana babanın dijital kimliğine mi yoksa çocuğun gelişimine mi katkı sağladığı sorgulanmalıdır. Ana baba çocuğu ile ilgili paylaşım yaparken, zaman zaman bunları yalnızca aile üyeleri veya yakın dostların bulunduğu kapalı bir grupta paylaşarak hatıra olması amacıyla hareket edebilmektedir. Halbuki sosyal medyanın çocukların fotoğrafını hatıra olması amacıyla saklayabileceğimiz bir veri depolama aracı olmadığı anlaşılmalıdır. Ana babalar, halka açık olarak beyan etmekten rahatsızlık duymayacakları hiçbir veriyi, sosyal medyada da paylaşmamalıdırlar. Çünkü sosyal medya sınırları olmayan, paylaşılan verinin kime ulaştı̆̆ının tam olarak kontrol edilemediği bir ortamdır.

Ana babalar çocukları ile ilgili paylaşım yaparlarken sosyal medya platformlarının güvenlik ayarları kısmından gizlilik ayarlamaları yapmalıdırlar. Çocuklara ilişkin sağlık problemleri ile ilgili paylaşım yapılırken, bu verilerin çocuğun tanınmasına izin vermeyecek şekilde anonimleştirilmesi gerekir ${ }^{61}$. Sosyal medya paylaşımlarında mümkünse çocuğun ismine, doğum tarihine yer verilmemelidir'². Çünkü bu veriler çocukları kimlik hırsızlığına maruz bırakabilir. Çocuğun yaşadığı yeri, okulu, günlük rutinlerini ifşa edip çocukları istismar tehlikesine maruz bırakabilecek paylaşımlar yapılmamalıdır. Benzer şekilde çocuklara

60 ERIŞİR, Rabia Merve/ ERIŞİR, Deniz, "Yeni Medya ve Çocuk: Instagram Özelinde "Sharenting" ("Paylaşananababalık") Örneği, Yeni Medya, Sayı: 4-5, 2018, s. 50- 64, s. 60, 61; UZUN, s. 5, 6.

61 ERIŞİR/ ERIŞİR, s. 61; YAVUZ, S. 39, 40.

62 YAVUZ, s. 39, 40. 
ilişkin paylaşım yapılırken coğrafi konum ve yer etiketlemesi yapılmamalıdır. Çocukları hedef alan kişilerin çocuğa ulaşmasını kolaylaştıracak doğum günü, mezuniyet töreni, sünnet dügünü, bebek, çocuk gibi doğrudan çocuğu gösteren etiketlemelerden kaçınılmalıdır. Dijital fotoğraf makineleri veya cep telefonları ile fotoğraf ya da video çekimi halinde görüntünün coğrafi olarak nerede çekildiğini gösteren "EXIF" bilgisi oluşturulmaktadır. Çocuklara ilişkin paylaşım yapılmadan önce bu yer tespit bilgisinin kaldırılması yararlı olur.

Çocuk ile ilgili paylaşım yapılmadan önce, ayırt etme gücü bulunan çocuğun muhakkak görüşü sorulmalı, rızası alınmalıdır ${ }^{63}$. Çocuk kendisi hakkında paylaşım yapılmasını istemediğinde, onun bu talebine uyulmalı ve hatta gerekirse önceki paylaşımlar da silinmelidir. Çocukların giysisiz görüntüleri paylaşılmamalıdır64. Çocuğa ilişkin mutlaka paylaşım yapılmak isteniyorsa da dijital çocuk kaçırmaya (digital kidnapping) karşı çocuğun tek başına bir fotoğrafından ziyade yanında bir yetişkin ile çekilmiş fotoğrafının kullanılmasına dikkat edilmelidir. Bunun yanı sıra ailelerin ve çocukların sosyal medyaya ilişkin farkındalığını arttırmak amacıyla sosyal medya okuryazarlığı eğitimleri verilmelidir. Anaokulu ve kreş de dahil olmak üzere okullarda görev yapan öğretmen ve eğiticilerin de bu eğitimi alması sağlanmalıdır. Böylece onların da çocuklara ilişkin yaptıkları paylaşımlarda daha sorumlu davranmaları sağlanmış olur.

\section{SONUÇ}

Internet ve sosyal medya, hızlı gelişimi ile çok kısa süre içerisinde herkesin paylaşım yaptığı ve kendisini ifade etme aracı olarak gördüğü platformlara dönüşmüştür. Aileler dış dünyada çocuklarını korumak için türlü önlemler alırken, dijital dünyanın kuralları konusundaki eğitimsizlik ve belirsizlikler sebebiyle çoğu zaman farkında dahi olmaksızın, yaptıkları sosyal medya paylaşımları ile çocuklarını kamunun gözü önüne savunmasız olarak birakabilmektedirler. Ana 
babaların sosyal medyada paylaşım yaparken gerekli gizlilik ayarlamalarını yapmayı ihmal etmeleri, paylaştıkları verinin hassasiyetini göz ardı etmeleri, bu gönderilerin yalnızca sınırlı sayıda kişi tarafından görüleceği yanılgısı, çocukların kişilik hakkını derinden ihlal edebilmektedir. Çocukların dijital ayak izleri, doğumlarından evvel başlayıp gittikçe artmaktadır. Bu nesil öncesinde hiçbir neslin bu kadar geniş bir dijital ayak izi bulunmamaktadır. Bu denli çok paylaşımın, ileride çocuğun gelişimini, toplum tarafından algılanışını nasıl şekillendireceği belirsizdir. Özellikle de ayırt etme gücü bulunmayan çocuklara ilişkin yapılan paylaşımlar, çocuğun özel hayatını üçüncü kişilere ifşa etmektedir. Yapılan bu paylaşımlar sonucu toplumda çocuğa ilişkin olumsuz bir alg1 oluşabilmekte, çocuk sosyal ortamlardan dışlanabilmektedir. Ana babaların çocuklarına dair yaptıkları bu paylaşımlar, internete yüklenen hiçbir verinin tam anlamıla silinememesi özelliği dolayısıyla adeta birer dijital dövme niteliğindedir. Bir yetişkin, sosyal medyada kendisine dair bir veri paylaştığında, kontrol alanı içerisinde özgür iradesiyle ne kadar veriyi, hangi koşullar içerisinde paylaşacağına karar vermektedir. Halbuki çocuklar, ana babaları onlar için bu sınırı çizmediği müddetçe, kendi dijital verileri üzerinde söz hakkı sahibi değildirler. Bu durum ile ilgili bir diğer sorun ise, çocuklara dair kontrolsüz bir biçimde paylaşım yapmanın normalleşmesidir. Hukuk sistemleri henüz bu kişilik hakkı ihlaline anlamlı ve hızlı sonuç verecek bir sistem bulamamışken, paylaşımların gün geçtikçe artması endişe vericidir.

Ana babaların çocukları ile ilgili olarak kişilik hakkını ihlal edecek nitelikte sosyal medyada paylaşım yapmalarına sharenting adı verilmektedir. $\mathrm{Bu}$, internetin gelişimi ve kontrolsüz veri paylaşımının ortaya koyduğu pek çok ihlalden biridir. Hatta bazı ailelerde bu durum çocuğun neredeyse her anının sosyal medyada paylaşıldığı, çocuğun adeta ekranda büyüdüğü ve tüm özel yaşamının sınırsız bir biçimde kamuya açıldığı bir over-sharenting durumu da teşkil edebilmektedir. Konuyu bu denli önemli kılan, bu ihlallerin çocuklara birincil düzeyde koruma sağlaması gereken ebeveynleri tarafından yapılıyor olmasıdır. 
Daha da vahimi ise, ailelerin bu ihlallerin ve paylaşımların sonucu olarak çocuklarını içine atmış olabilecekleri tehlikenin farkında olmamalarıdır. $\mathrm{Bu}$ paylaşımların kendi yaşamına özendirme çabasından, çocuklar ile ilgili alanlarda deneyimlerini paylaşmaya kadar giden pek çok amacı olabilir. Amaç ne olursa olsun, çocuğun yararı tehlikeye düştüğü anda çocuğun kişilik hakkı ihlal edilmiş olur ve ana babanın velayet yükümlülüklerini yerine getirmedikleri söylenebilir. Ana babalar, bu paylaşımlar yoluyla maddi gelir elde etmeyi de hedefleyebilmektedirler. Çocuklar adeta bir birey değil de eşya gibi görülerek çocuğu merkeze koyan pek çok paylaşım yapılmaktadır. Dahası bu paylaşımlar üçüncü kişilerin çocuğun görüntüsünü çalarak kendi çocuklarıymış gibi başka hesaplar altında paylaşım yapmaları ile ortaya çıkan dijital çocuk kaçırmaya da zemin hazırlamaktadır. Bu ihlaller ana babanın velayet hakkını, hukuki sorumluluk bakımından tartışmaya açabilmektedir.

Velayet, ana baba için hem bir hak hem de bir yükümlülüktür. Bu yüzden hızla değişen dijital dünyanın ihtiyaçlarına ilişkin olarak velayet hakkının da buna uygun olarak şekillenmesi gerekir. Ana baba, sosyal medyada çocuk hakkında paylaşım yaparken, mutlaka ayırt etme gücü olan çocuktan geçerli rıza almalıdırlar. Çocuk bu rızayı vermiyorsa, ana babanın sosyal medya paylaşımını yapmamaları gerekir. Ayırt etme gücüne sahip olmayan çocuklar bakımından ise, onları korumak ilk başta ana babanın görevidir. Bu sebeple ana babalar, çocuğun ileride kişilik hakkına zarar verebilecek materyalleri internet ortaminda paylaşmamalıdırlar. Ana babanın velayet hakkının sınırını çocuğun üstün yararı, kişilik hakkı ve mahremiyeti oluşturur. Sosyal medya paylaşımları aracılığıyla kendisini ifade eden ana babanın ifade özgürlüğü ile çocuğun menfaatleri çatıştığında her halükârda çocuğun korunmasına öncelik verilmelidir. Ana baba, bu verileri üstün kamu yararı amacıyla toplumu bilgilendirmek için paylaştığını ileri sürse dahi, üstüm kamu yararı dahi çocuğun üstün yararından daha önemli değildir.

Sharenting sonucu ihlal gerçekleştiğinde ilk olarak kişilik hakkını koruyucu davalardan yararlanılabilir. Ayırt etme gücüne sahip çocuk, bu davaları kendisi de yasal temsilcisinin iznine tabi olmaksızın açabilir. 
Ayırt etme gücüne sahip olmayan çocuklar bakımından ise, ihlali gerçekleştirmeyen ebeveyn bu davaları açabileceği gibi, her iki ebeveynin de bu ihlallere sebep olması durumunda her ilgili tarafından çocuğun kişilik hakkının korunması talep edilebilir. Bu çerçevede yapılan paylaşımın silinmesi, bir daha çocuğa ilişkin paylaşım yapılmaması, ana babanın denetlenmesi, rehabilite edilmesi, ana babanın davranışları sebebiyle paylaşım yaptıkları yolla çocuktan özür dilemeleri gibi pek çok karar verilebilir. Bunun yanı sıra sharenting aynı zamanda velayet hakkından doğan yükümlülüklerin ihlali teşkil edebilir. Bu takdirde mahkeme, velayet hakkına sahip ana baba hakkında giderek artan ağırlıkta yaptırımlar uygulayabilir. Ayrıca çocuk, ayırt etme gücüne sahip olduğunda mahkemeye başvurarak unutulma hakkını da kullanabilir.

Ana babalar çocukları ile ilgili paylaşım yaparken çok dikkatli davranmalı ve çocuğun kişilik hakkını zedeleme riski olan paylaşımlar yapmaktan kaçınmalıdır. Paylaşım yapılırken, çocuğun yerini ve rutinini ifşa etmeyen, ileride görmekten utanç duymayacağı, onu toplum içinde rencide etmeyen, içinde çocukla beraber en az bir yetişkinin olduğu paylaşımlar yapılmalı ve çocuk buna karşı çıktığında paylaşımın içeriğine ve amacına bakılmaksızın veri kaldırılmalıdır. Çocuğun, kendi dijital ayak izi üzerindeki kontrol gücü arttırılmalıdır. 


\section{KAYNAKLAR}

AKGÜL, Aydın, "Kişisel Verilerin Korunmasında Yeni Bir Hak: “Unutulma Hakkı" ve AB Adalet Divanı'nın "Google Kararı", TBB Dergisi, Say1:116, 2015, s. 11- 38.

AKINTÜRK, Turgut/ ATEŞ KARAMAN, Derya, Aile Hukuku, İstanbul, 2016.

AKİPEK, Şebnem, “Özel Hukuk ve İnternet", http://inettr.org.tr/inetconf5/tammetin/hukuk.html, (Erişim Tarihi: 14.07.2021).

AKKURT, Sinan Sami, "Çocuğun Kişiliğinin Korunması ve Velâyetin Belirlenmesinde Çocuğun Menfaati Olgusu", Prof. Dr. Rona Serozan'a Armağan, Cilt I, Editör: ENGİN, Baki İlkay, İstanbul, 2010, s. 91- 120.

AKYÜZ, Emine, Çocuk Hukuku, Çocukların Hakları ve Korunması, Ankara, 2016, (Kısaltılmışı: AKYÜZ, 2016).

AKYÜZ, Emine, Ulusal ve Uluslararası Hukukta Çocuğun Haklarının ve Güvenliğinin Korunması, Ankara, 2000, (Kısaltılmışı: AKYÜZ, 2000).

AKYÜZ, Emine, "Velâyet ve Çocuğun Korunması", Prof. Dr. Ali Naim İnan'a Armağan, Editörler: ÜNAL, Mehmet/ BAŞPINAR, Veysel/ OZANOĞLU, Hasan Seçkin Ozanoğlu/ YILMAZ, Süleyman, Ankara, 2009, s. 111-156, (Kısaltılmışı: AKYÜZ, 2009). AKYÜZ BİLGE, Canan, Unutulma Hakkı ve Türk Hukuku'ndaki Görünümü, Yüksek Lisans Tezi, Ankara, 2019.

ANTALYA, Gökhan, “Manevi Zararın Belirlenmesi ve Manevi Tazminatın Hesaplanması -Türk Hukukuna Manevi Zararın İki Aşamalı Olarak Belirlenmesine İlişkin Bir Model Önerisi-“, Marmara Üniversitesi Hukuk Fakültesi Hukuk Araştırmaları Dergisi, Say1: 22, 2016, s. 221-250.

BATTERSBY, Lucy, "Millions Of Social Media Photos Found On Child Exploitation Sharing Sites", https://www.smh.com.au/national/millions-of-social-media- 
photos-found-on-child-exploitation-sharing-sites-20150929-

gjxe55.html, (Erişim Tarihi: 24.06.2021).

BAYGIN, Cem, Soybağı Hukuku, İstanbul, 2010, s. 326.

BEARAK, Steven, "Digital Kidnapping: What It Is and How to Keep Your Kids Safe on Social Media, Digital kidnapping is growing rapidly, here's what you need to know", https://www.parentmap.com/article/kidnappers-kids-photosdigital-kidnapping-social-media, (Erişim Tarihi: 24.06.2021).

BUCHER, Andreas, Natürliche Personen und Personlichkeitschutz, Basel, 2009.

ÇÖPÜR, Mazlum/ ÜNERİ, Özden Şükran/ AYDIN, Erkan/ BAHALI, Mustafa Kayhan/ TANIDIR, Canan/ GÜNEŞ, Hatice/ ERDOĞAN, Ayten, "İstanbul İli Örnekleminde Çocuk ve Ergen Cinsel İstismarlarının Karakteristik Özellikleri", Anadolu Psikiyatri Dergisi, 2012; Sayı: 13, s. 46-50.

DURAK, Yasemin, “İnternet Yoluyla Kişilik Haklarına Saldırı ve Hukuki Koruma", Selçuk Üniversitesi Hukuk Fakültesi Dergisi, Cilt: 22, Sayı: 1, 2014, s. 101- 125.

DURAL, Mustafa/ ÖĞÜZ, Tufan, Türk Özel Hukuku Cilt II Kişiler Hukuku. İstanbul, 2017.

DURAL, Mustafa/ ÖĞÜZ, Tufan/ GÜMÜŞ, M. Alper, Türk Özel Hukuku, Cilt III Aile Hukuku, İstanbul 2018.

DÜLGER, Murat Volkan, "Sağlık Hukukunda Kişisel Verilerin Korunması ve Hasta Mahremiyeti", İstanbul Medipol Üniversitesi Hukuk Fakültesi Dergisi Cilt:1, Sayı: 2, 2015, s. 4380, s. 51.

ELÇİN, Evgen Gülçin, “Çocuğun Menfaati Gereği Çocukla İlgili Uyuşmazlıklarda Görüşünün Alınmaması Gereken Durumlar", Çocuk Hakları Çalışmaları I, Editörler: ELÇİN, Evgen Gülçin/ GENÇ ARIDEMIR, Arzu, İstanbul, 2017, s. 1- 26.

ELÇİN GRASSINGER, E. Gülçin, “Çocuğun Menfaati Gereği Görüşünün Alınmaması Gereken Durumlar", Prof. Dr. Rona Serozan'a 
Armağan, Cilt I, Editör: ENGİN, Baki İlkay, İstanbul, 2010, s. 823846, (Kısaltılmış1: ELÇİN GRASSINGER, Çocuk).

ELÇİN GRASSINGER, Gülçin; Türk Medeni Kanununda Yer Alan Velayet Hükümleri Kapsamında Küçügün Kişi Varlığının Korunması İçin Alınacak Tedbirler (MK md.346, md. 347, md.348), İstanbul, 2009, (ELÇİN GRASSINGER, Velayet).

EREN, Fikret, Borçlar Hukuku Genel Hükümler, Ankara, 2017.

ELMALICA, Hasan, “Bilişim Çağının Ortaya Çıkardığı Temel Bir İnsan Hakkı Olarak Unutulma Hakkı", Ankara Üniversitesi Hukuk Fakültesi Dergisi, Cilt:65, Sayı: 4, 2016, s. 1603-1636.

ERIŞİR, Rabia Merve/ ERIŞİR, Deniz, "Yeni Medya ve Çocuk: Instagram Özelinde "Sharenting" ("Paylaşananababalık") Örneği, Yeni Medya, Sayı: 4-5, 2018, s. 50- 64.

ERLÜLE, Fulya, Bedensel Bütünlügün İhlalinde Manevi Tazminat, Ankara, 2011.

FANKHAUSER, Roland / FISCHER, Nadja, “Kinderfotos auf Facebook oder wenn Eltern die Persönlichkeitsrechte ihrer Kinder verletzen", Brennpunkt Familienrecht, Festschrift für Thomas Geiser zum 65. Geburtstag, Editörler: FANKHAUSER, Roland/ REUSSER, Ruth E./ SCHWANDER, Ivo, Zürich, 2017, s. 193- 215. GİRGIN, Ömer Ali/ GÖNAL, Seray, “Çocuğun Kişisel Verilerinin Sosyal Medyada Ebeveyn Tarafından Paylaşılmasının Hukuki Sonuçları", Türkiye Adalet Akademisi Dergisi, Sayı: 44, Ankara, 2020, s. 99- 128.

GÖRGEÇ, Başak, Türk Medeni Kanunu'nda Velayet Hükümleri ve Özellikle Çocuğun Korunması, Yayınlanmamış Yüksek Lisans Tezi, İstanbul, 2011.

GÜLENER, Serdar, “Dijital Hafızadan Silinmeyi İstemek: Temel Bir İnsan Hakkı Olarak “Unutulma Hakkı”, TBB Dergisi, Sayı:102, 2012, s. 219- 240.

GÜLTEKIN, Esra, “Çocuğun Kişilik Hakkının Ana-Baba Tarafından Sosyal Medya Aracılığıyla İhlalinin Hukuki Görünümü", Çocuk ve Medeniyet, Sayı: 1, 2018, s. 103- 143. 
HILL, Kashmir/ KROLIK, Aaron, "How Photos of Your Kids Are Powering Surveillance Technology, Millions of Flickr images were sucked into a database called MegaFace. Now some of those faces may have the ability to sue.", https://www.nytimes.com/interactive/2019/10/11/technology/fli ckr-facial-recognition.html, (Erişim Tarihi: 24.06.2021).

HONSELL, Heinrich/ VOGT, Nedim Peter/ GEISER, Thomas, Basler Kommentar, Zivilgesetsbuch I, Basel- Genf- München, 2010.

İMAMOĞLU, Hülya, “Çocuğun Kişiliğinin Ana Babaya Karş1 Korunması, Ankara Üniversitesi Hukuk Fakültesi Dergisi, Ankara, 2005, Cilt: 4, Sayı: 2, s. 183- 218.

KANDİLLİ, Elif, Sağlık Hukukunda Etik Açısından Kişisel Veriler ve Mahremiyet Hakkı, Yayınlanmamış Yüksek Lisans Tezi, İstanbul, 2019.

KARABAĞ BULUT, Nil, “Basın Özgürlüğü ile Özel Yaşama Sayg1 Gösterilmesi Hakkı Arasında Kurulacak Dengenin, Avrupa İnsan Hakları Mahkemesi'nin von Hannover v. Almanya Vakasına İlişkin 24 Haziran 2004 Tarihli Kararı Işığında Değerlendirilmesi", Prof. Dr. Rona Serozan'a Armağan, Cilt: II, İstanbul, 2010, s. 1055-1112.

KARAN, Ulaş, İfade Özgürlügü, Anayasa Mahkemesine Bireysel Başvuru El Kitapları Serisi - 2, Avrupa Konseyi, Strasbourg Cedex- Ankara, 2018.

KESİCİĞLU, Oğuz Serdar, "Instagramda "Okul Öncesi” Etiketiyle Yapılan Paylaşımların İncelenmesi", 6. Uluslararası Okul Öncesi Eğitimi Kongresi Tam Metin Bildiri Kitabı, 30 Aralık 2019, Kars, s. 531- 538.

KESKİN, Dilşad, Objektif Manevi Zarar Teorisi Açısından Manevi Tazminat, Ankara, 2016.

KILIÇOĞLU, Ahmet, "Basın Özgürlüğünün Suistimali”, TBB Dergisi, Say1: 3-4, 1993, s. 385- 388, s. 386, (Kısaltılmışı: KILIÇOĞLU, 1993). 
KILIÇOĞLU, Ahmet, “Kişilik Haklarına Basın Yoluyla Saldırılar Bakımından Medeni ve Borçlar Kanunumuzda Yapılan Değişiklikler", TBB Dergisi, Sayı: 3, 1990, s. 371- 400, (Kısaltılmışı: KILIÇOĞLU, 1990).

KIRKEY, Shirley, “Do You Know Where Your Child's İmage İs? Pedophiles Sharing Photos From Parents' Social Media Accounts", https://nationalpost.com/news/canada/photosshared-on-pedophile-sites-taken-from-parents-social-mediaaccounts, (Erişim Tarihi: 24.06.2021).

OĞUZMAN, Kemal/ SELİÇİ, Özer/ OKTAY-ÖZDEMİR, Saibe, Kişiler Hukuku (Gerçek ve Tüzel Kişiler), İstanbul, 2012.

ÖZBEY, Özcan, “Avrupa İnsan Hakları Sözleşmesi Işı̆̆ında İfade Özgürlüğü Kısıtlamaları”, TBB Dergisi, Sayı: 106, 2013, s. 41- 92. ÖZBUDUN, Ergun, Türk Anayasa Hukuku, Ankara, 2010.

ÖZCAN BÜYÜKTANIR, Burcu G., Çocuğun Kişilik Hakkı ve Çocuğun Kişilik hakkının Hukuka Aykırı Fiillere Karşı Korunması, Ankara, 2019.

ÖZDEMİR, Hayrunnisa, “Çocukların Kişisel Verilerinin Sosyal Medya Aracılığıyla İşlenmesi", Selçuk Hukuk Kongresi 2020 Özel Hukuk Tebliğleri Tam Metin Kitabı, Editörler: UYUMAZ, Alper /AKÇAAL, Mehmet / TÜZEMEN ATIK, Ebru, Nobel Akademik Yayıncilik, s. 303- 328.

ÖZTAN, Bilge, Aile Hukuku, Ankara, 2015.

SCHIMKE, Anna, "Rechtliche Rahmenbedingungen der Veröffentlichung von Kinderfotos im Netz durch Eltern", Neue Zeitschrift Für Familienrecht, Say1: 19, 2019, s. 851-858.

SERÇEMELİ, Ceyhun, "Ebeveynlerin Sosyal Medyadaki “OverSharenting" Davranışlarının Hukuki Açıdan Değerlendirilmesi", TURAN-SAM Uluslararası Bilimsel Hakemli Dergisi; p-ISSN: 1308-8041, e-ISSN: 1309-4033; Y1l: 2020; Ay: Aralı;; Cilt: 12/SONBAHAR, Sayı: 48, s. 229- 237.

SEROZAN, Rona, Çocuk Hukuku, İstanbul, 2005, (Kısaltılmış1: SEROZAN, Çocuk). 
SEROZAN, Rona, Medeni Hukuk, İstanbul, 2011, (Kısaltılmışı: SEROZAN, Medeni).

T.C. Başbakanlık Sosyal Hizmetler ve Çocuk Esirgeme Kurumu/ UNIFEC; "Türkiye'de Çocuk İstismarı ve Aile İçi Şiddet Araştırması Özet Raporu", 2010, https://www.unicef.org/turkey/sites/unicef.org.turkey/files/2019 -02/cocuk-istismari-raporu-tr_1.pdf, (Erişim Tarihi: 24.06.2021).

TEZİÇ, Erdoğan, Anayasa Hukuku, İstanbul, 2017.

The Telegraph, "Parents discover children's Facebook photos on Russian paedophile website", 13.01.2015, https://www.telegraph.co.uk/news/uknews/crime/11342175/Par ents-discover-childrens- Facebook-photos-on-Russianpaedophile-website.html, (Erişim Tarihi: 24.06.2021).

UZUN, Sevde, "Velayet Hakkı Bağlamında Çocuğun Görüntüsünün Sosyal Medyada Paylaşılması ve Ortaya Çıkabilecek Hukuki Meseleler", http://humanistburo.org/dosyalar/humdosya/Cocugun\%20Gor untusunun\%20Sosyal\%20Medyada\%20Paylasilmasina\%20Dair \%20Hukuki\%20Meseleler\%20(S.Uzun).pdf, (Erişim Tarihi: 22.06.2021).

von CAEMMERER, Ernst, “Alman Hukukuna Göre Kişiliğin Özel Hukuk Yönünden Korunması", Çeviren: ÖZSUNAY, Ergun, İstanbul Üniversitesi Mukayeseli Hukuk Araştırmaları Dergisi, Cilt: 7, Say1: 10, 1973, s. 69- 83.

YAVUZ, Can, "Sosyal Medya Ebeveynliği ve Çocukların Unutulma Hakkı", İzmir Barosu Dergisi, Ocak 2020, s. 15-51.

YILDIZ, Tuba, Kişilik Hakları Açısından Unutulma Hakkı, Yayınlanmamış Yüksek Lisans Tezi, Ankara, 2019.

YÜKSEL, Sera Reyhani; Velayet Hakkının Anayasal Sınırları, İstanbul, 2016. 